\title{
Bacteriological and antibiotic profile of infection among infants in the post-neonatal period at a tertiary care hospital in South India
}

Bacteriological and antibiotic profile

\author{
Santhosh J. Thattil \\ Department of Microbiology, Malabar Dental College, Thrissur, India, and \\ T.A. Ajith \\ Biochemistry, Amala Institute of Medical Sciences, Thrissur, India
}

\begin{abstract}
Purpose - Severe bacterial infection is a major cause of neonatal morbidity and mortality worldwide. Geographical-based demographic laboratory and clinical data are required to get a conclusion about the bacterial infection and their antibiotic susceptibility for the empiric antibiotic treatment in infants who presented with suspected infection. This study was aimed to find the most prevalent bacterial infection and antibiotic sensitivity among infants in the post-neonatal period presented at a tertiary care centre in South India.

Design/methodology/approach - A cross-sectional study was designed among infants (29 days to 1 year old) presented with suspected infection in the paediatric department. Infants with positive culture report were analysed for the bacteriological and antibiotic profile from the medical records. Antibiotic sensitivity was determined for the isolated bacteria according to standard procedure and data statically analysed.

Findings - Total of 218 samples (138 male and 80 female) were analysed. Most of the samples $(171 / 218,78.4 \%)$ were throat swab $(p=0.0247)$. Only one sample was cerebrospinal fluid from case of meningitis. Sample from upper RTI was major (162/218, 74.3\%) with male dominance followed by stool samples from cases of diarrhoea $(22 / 218,10.0 \%)$. Staphylococcus aureus was the major organism identified in $46 / 171(26.9 \%)$ throat swabs. The most sensitive antibiotic against bacteria isolated from throat swab and CSF was gentamicin and cloxacillin. Netilmicin and piperacillin plus tazobactam were the sensitive antibiotics against bacteria isolated from stool, ear secretion and urine samples.

Originality/value - Upper RTI was the prevalent bacterial infection followed by diarrhoea in infants in the post-neonatal period. Klebsiella pneumoniae was the common organism identified in the overall report followed by $E$. coli and S. aureus. Community-based awareness should be provided to follow good hygiene regularly in child care. Furthermore, avoid delay in seeking treatment and provide the medicine prescribed at the right time and in the right dose to limit the morbidity and bacterial resistance.
\end{abstract}

Keywords Antibiotic susceptibility, Bacteremia, Neonates, Neonatal sepsis, Urinary tract infection, India

Paper type Research paper

\section{Introduction}

A serious bacterial infection is one of the major causes of neonatal mortality worldwide. Despite high-resource settings, diagnosis is challenging due to nonspecific signs and symptoms in neonates. Incidence of serious bacterial infections in infants during the postneonatal period, identification of the organism and appropriate antibiotic selection remains a major challenge to clinicians. Bacterial strains' resistance to antibiotics is the common cause of serious bacterial infections in febrile post-neonatal infants. In most cases, the initial antibiotic

(C) Santhosh J. Thattil and T.A. Ajith. Published in Journal of Health Research. Published by Emerald Publishing Limited. This article is published under the Creative Commons Attribution (CC BY 4.0) licence. Anyone may reproduce, distribute, translate and create derivative works of this article (for both commercial and non-commercial purposes), subject to full attribution to the original publication and authors. The full terms of this licence may be seen at http://creativecommons.org/licences/by/4.0/ legalcode

Received 1 April 2020 Revised 15 June 2020 Accepted 29 July 2020 
JHR

36,2

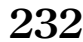

therapy will be changed after the identification of the organism in culture. Therefore, antibiotic susceptibility patterns of bacteria are necessary to know the local surveillance of pathogens and also very critical to determine appropriate antibiotic therapy. A recent systematic review reported that urinary tract infection (UTI) was the most common bacterial infection in young infants [1, 2]. Wang et al. reported a wide local variation in bacterial infections [3]. Studies reported that febrile illnesses such as pneumonia, UTI, blood-stream infections, and meningitis were the most severe bacterial infections in Indian infants [4-7].

Neonatal sepsis was associated with broad ranges of bacteria that showed variation in the antibiotic susceptibility pattern [8]. Widespread use of antibiotics has resulted in Streptococcus pneumoniae, one of the bacteria that causes life-threatening infections in infants in South India, but is non-susceptible to some commonly used antibiotics [9]. This warrants the necessary modification of existing empirical therapy regimens and implementation of effective preventive strategies to combat the emergence of antibiotic resistance in treating infants. In order to achieve a significant reduction of infants' morbidity and mortality in India, documentation of the demographic and geographical details of changes in cause-specific neonatal infection is required [10]. Hence, the geographical-based demographic, laboratory and clinical data are required to get a conclusion about the bacteria and their antibiotic susceptibility to start the empiric treatment in infants who presented with suspected invasive bacterial infection [11]. At present, data on neonatal infections, mainly the types of bacterial infections, are scant or incomplete among the post-neonatal infants in the Indian community setting. This study aimed to describe the bacterial infection, type of bacteria, and their antimicrobial profile in post-neonatal infants presented with infection at a tertiary care hospital.

\section{Methods}

Study design and population

A cross-sectional study was designed among the infants (29 days to 1 year old) presented with a suspected bacterial infection in the Paediatric Department of a tertiary care children's hospital in central Kerala, India between October 2019 and March 2020. All infants in the postneonatal period with positive pathogenic bacteria identified in the biological sample culture were included in the study. Cases with incomplete medical records or cases with samples positive in oral secretion or gastrointestinal aspirations of unknown infection were excluded from the study. Informed consent was taken from the parent/guardian of infants. The study was performed in accordance with the procedures of the institutional research committee.

\section{Sample size calculation}

Based on the prevalence $(p)$ of respiratory tract infection, $65 \%$ (in the preliminary study conducted in this lab), the relative precision $d, 10 \%$ of $p$ and $Z_{1-\alpha / 2}=1.96$ at $5 \%$ significant level, the minimum sample size was calculated as 216 using the equation $n=\left(Z_{1-\alpha / 2}\right)^{2} p$ $(1-p) / d^{2}$

\section{Study procedure}

Results of only positive bacterial culture of urine, stool, CSF, ear secretion and throat swab and the corresponding antimicrobial susceptibilities were collected from the microbiology lab database. The bacterial identification was done as per the standard procedure [12]. The antibiotic susceptibility testing was done by the standardized disc diffusion method (KirbyBauer Method) described by Bauer et al. [13].

Antibiotic discs used for throat swab with gram-negative bacilli isolated were amoxicillin, gentamicin, cephalexin, cefuroxime, cefotaxime, (instead of cefotaxime ceftazidime used for Pseudomonas aeruginosa), co-trimoxazole, chloramphenicole, tigecyclin, ciprofloxacin, 
imipenem, piperacillin + tazobactum, and polymixin B. For throat swab specimens, isolated gram-positive cocci, the antibiotic discs used were penicillin, amoxicillin, cloxacillin, gentamicin, netilmicin, cephalexin, ceforoxime, cefotaxime, erythromycin, azithromycin, vancomycin and linezolid. For gram-positive cocci isolated from urine/stool/blood/CSF/ear swab, penicillin, amoxicillin, cloxacillin, gentamicin, netilmycin, cephalexin, cefuroxime, ciprofloxacin, erythromycin, azithromycin, vancomycin and linezolid were used. Nitrofurantoin was used in a bacterial isolate from urine only. For gram-negative bacilli isolated from urine/stool/blood/CSF/ear swab, the antibiotic discs used were amoxicillin, gentamicin, amikacin, netilmycin, cephalexin, cefuroxime, cefotaxime, cotrimoxazole, chloramphenicole, ciprofloxacin, tigecyclin, imipenem, (nitrofurantoin only inurine), piperacillin + tazobactum and polymixin B. These antibiotic discs were used as 12 discs in 2 plates. The cut-point for the susceptibility for each antibiotic was selected as per the CLSI guideline [14]. The case-specific clinically apparent infection was also collected from the medical record. The data were analysed for statistical significance.

\section{Statistical analysis}

All categorical data were analysed using SPSS (v.16, IBM, CA) software. Data expressed as frequency and percent incidence. A Chi-square test was used to find the statistical significance between the types of infection. $p<0.05$ was considered as significant.

\section{Ethical issue}

The study was conducted according to the Helsinki declaration, 1975 as revised in 2000 and approved by the Institutional Ethics Committee (NH/HRD/EC/04/2020).

\section{Results}

A total of 218 positive culture reports were included in the study whilst 12 reports with incomplete data on clinical presentation were excluded from the study. No mortality from the infection was found during the period of this study. Among the total reports, 171 reports were from a throat swab, reports on urine sample were only 19, stool samples were 22 and the CSF sample was only 1 . Among the total cases, 138 cases were males and the remaining were females. The male-to-female ratio was found to be 1.7:1. Over $90 \%$ of infants were febrile at the time of presentation. The major bacterial infection was respiratory tract infection (RTI) which was found in $171 / 218(78.4 \%)$ cases (Tables 1 and 2 ). A statistically significant difference was found between males and females with RTI from other infections $(\phi=0.0247)$. Among the RTI cases, 162/171 (94.7\%) were due to upper RTI with male dominance (Table 1). Lower RTI was only $9 / 171$ (5.2\%) (Table 2). However, no statistically significant difference $(\phi=0.2388$ ) could be found between the males and females with RTI. Staphylococcus aureus (46/171) was the major bacterium that causes $26.9 \%$ of RTI followed by Klebsiella pneumoniae (45/171, 26.3\%). There was a significant difference found between $S$. aureus and $K$. pneumonia associated RTI from others $(\phi=0.0491)$. Coagulase negative staphylococcus was isolated only in 16/171 (10.5\%) throat samples from infants presented with RTI (16 cases of upper RTI and 2 cases of lower RTI). Lower RTI was found only in 9/171 (5.2\%) cases with P. aeruginosa as the major bacteria $(4 / 171,2.3 \%)$. E. coli was the major organism found in the urine and stool samples of infants with UTI (Table 3) and diarrhoea (Table 4). Stool samples from infants presented with diarrhoea showed E. coli in 19/22 samples $(86.3 \%)$ while its presence in urine was 11/19 (57.8\%). Only 1 CSF sample with Staphylococcus aureus isolate was obtained during the period of the study which was from an infant presenting with meningitis (Table 5). Details of various bacteria isolated from 218 samples are depicted in Figure 1. K. pneumoniae was the common organism identified in overall culture (49/218, 
JHR
36,2

234

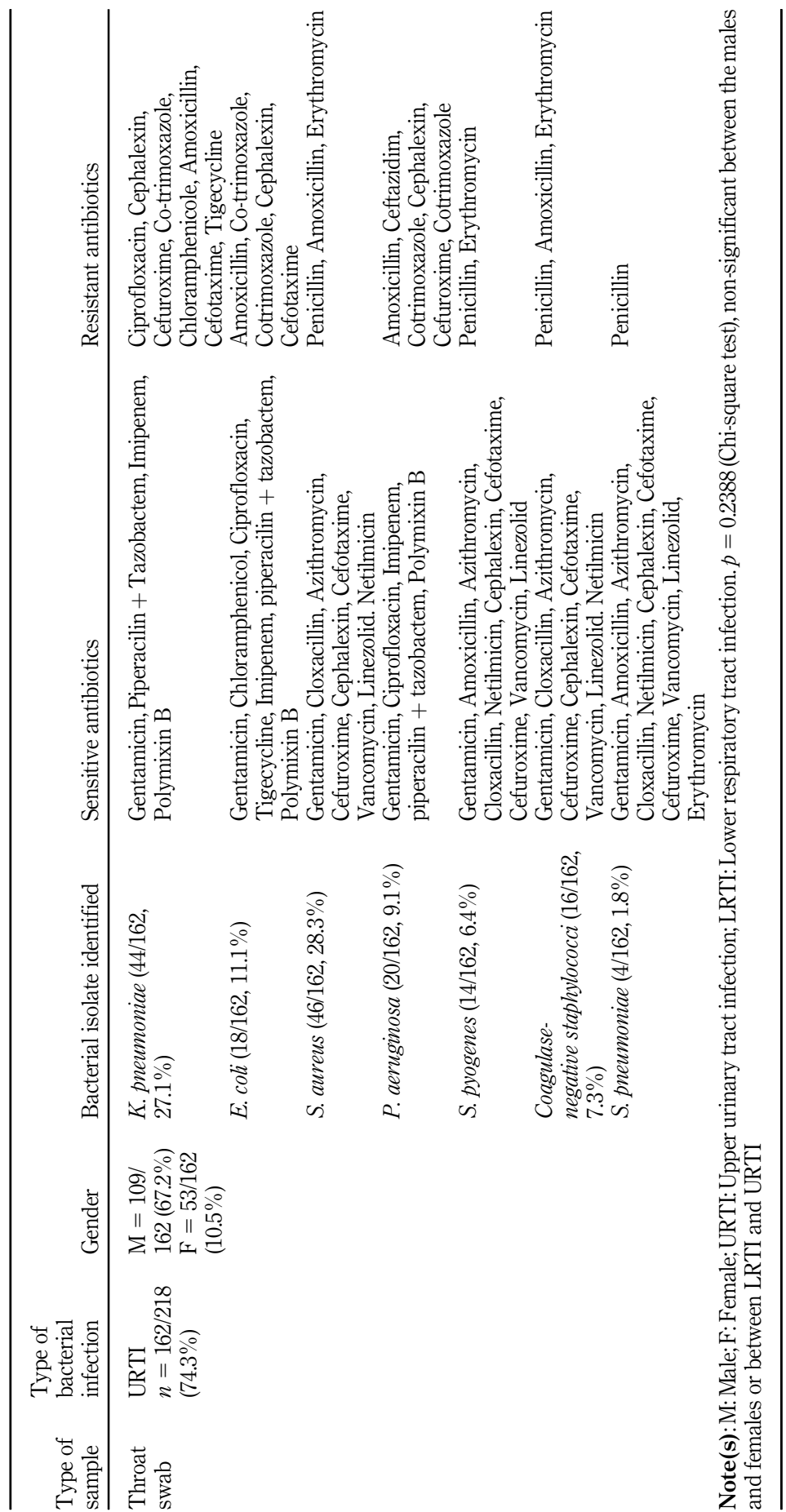

Table 1.

Distribution of bacterial infection among infants presented with upper and lower respiratory tract infection 


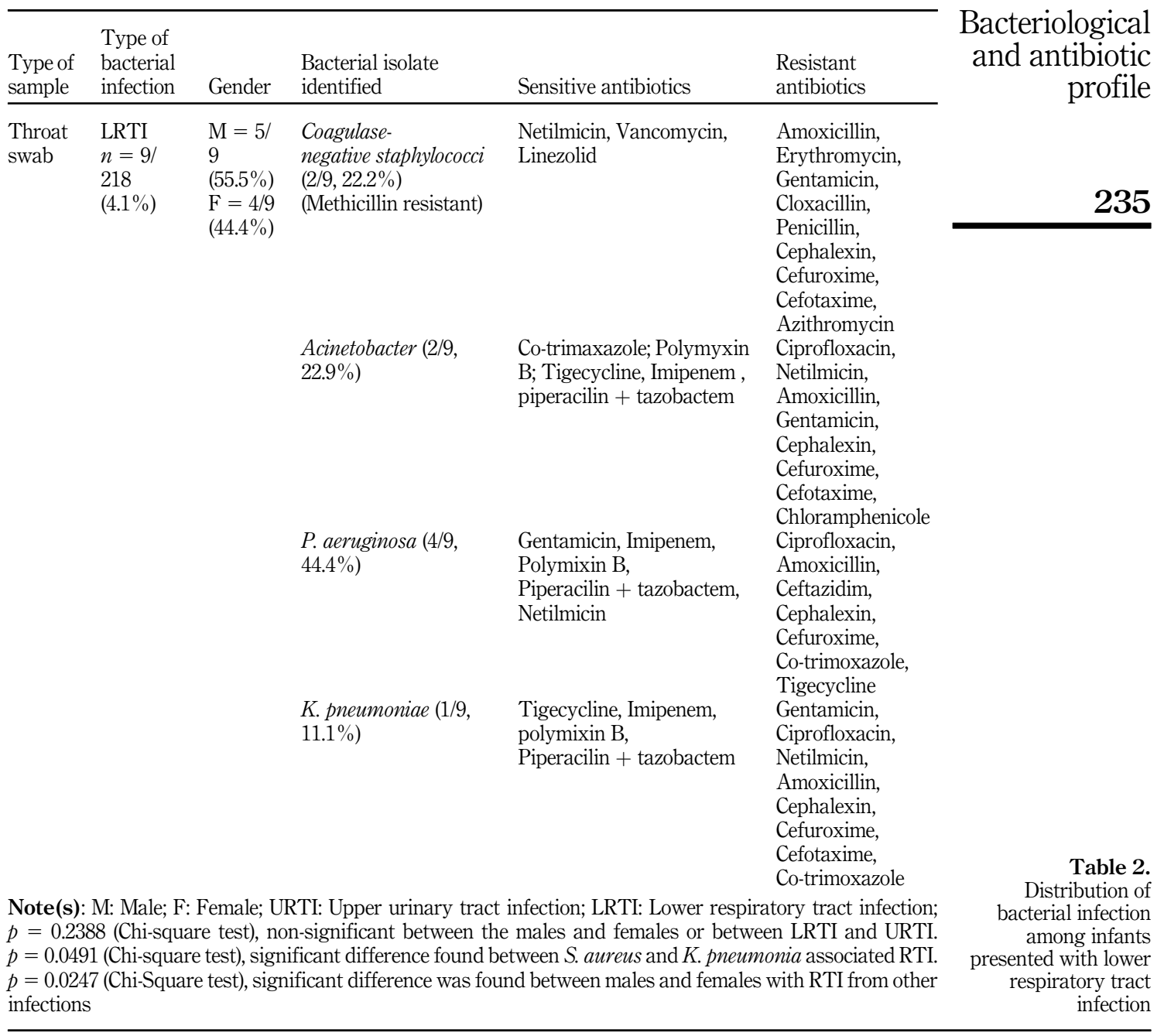

$22.4 \%$ ), followed by E. coli and S. aureus (48/218, 22.0\%). The most sensitive antibiotic against bacteria isolated in a throat swab and CSF samples were gentamicin and cloxacillin. Netilmicin and piperacillin plus tazobactam were the sensitive antibiotics against bacteria isolated from urine, stool, and ear secretion samples. Bacteria isolated from blood samples were sensitive to netilmicin. Ciprofloxacin was found resistant to most of the bacteria isolated from urine and stool while penicillin was resistant against bacteria isolated from a throat swab.

\section{Discussion}

Upper RTI is the major morbidity in infants in the post-neonatal period with $S$. aureus and $K$. pneumonia being the prevalent bacteria. Male infants were dominant. While $K$. pneumoniae was the major pathogen causing overall infection followed by $E$. coli and 
JHR
36,2

236

\begin{tabular}{|c|c|c|c|c|}
\hline $\begin{array}{l}\text { Type } \\
\text { of } \\
\text { sample }\end{array}$ & $\begin{array}{l}\text { Type of } \\
\text { bacterial } \\
\text { infection }\end{array}$ & Gender & $\begin{array}{l}\text { Bacterial isolate } \\
\text { identified }\end{array}$ & Sensitive antibiotics \\
\hline \multirow[t]{7}{*}{ Urine } & $\begin{array}{l}\text { UTI } \\
n=19 / \\
218 \\
(8.7 \%)\end{array}$ & $\begin{array}{l}\mathrm{M}=11 / \\
19 \\
(57.8 \%) \\
\mathrm{F}=8 / 19 \\
(42.1 \%)\end{array}$ & $\begin{array}{l}\text { E. coli }(11 / 19, \\
57.8 \%)\end{array}$ & $\begin{array}{l}\text { Chloramphenicol, Gentamicin, } \\
\text { Tigecycline, Ciprofloxacin } \\
\text { Netilmicin } \\
\text { Imipenem, Nitrofurantoin }\end{array}$ \\
\hline & & & $\begin{array}{l}\text { Proteus spp. (2/ } \\
\text { 19, 10.5\%) }\end{array}$ & $\begin{array}{l}\text { Piperacilin + tazobactem } \\
\text { Gentamicin, Imipenem, } \\
\text { Piperacilin + tazobactem }\end{array}$ \\
\hline & & & & Amikacin, Netilmicin \\
\hline & & & $\begin{array}{l}\text { K. pneumoniae } \\
(4 / 19,21.0 \%)\end{array}$ & $\begin{array}{l}\text { Tigecycline, Nitrofurantoin } \\
\text { Chloramphenicol, Amikacin, } \\
\text { Piperacilin + tazobactem } \\
\text { Netilmicin, Imipenem }\end{array}$ \\
\hline & & & & Nitrofurantoin \\
\hline & & & $\begin{array}{l}\text { Enterococcus } \\
\text { spp. }(1 / 19 \\
5.2 \%)\end{array}$ & Netilmicin, Vancomycin Linezolid \\
\hline & & & $\begin{array}{l}\text { MRSA (1/19, } \\
5.2 \%)\end{array}$ & Netilmicin, VancomycinLinezolid \\
\hline
\end{tabular}

Resistant antibiotics

Amoxicillin

Cephalexin, Cefuroxime Cefotaxime Amoxicillin, Cotrimoxazole, Cefotaxime Cephalexin, Cefuroxime Chloramphenicol Gentamicin, Amoxicillin, Cefotaxime, Cephalexin, Cefuroxime Ciprofloxacin Ciprofloxacin, Amoxicillin Azithromycin Penicillin, Cloxacillin, Gentamicin, Cephalexin, Erytromycin, Nitrofurantoin $5.2 \%)$ Ciprofloxacin, Amoxicillin Azithromycin

Penicillin, Cloxacillin, Gentamicin, Cephalexin, Erythromycin, Amikacin

Table 3.

Distribution of bacterial infection among infants presented with urinary tract infection (UTI)

Note(s): M: Male; F: Female; MRSA: Methicillin resistant Staphylococcus aureus

S. aureus. Diarrhoea was the second most prevalent morbidity with $E$. coli as the associated organism. The results of this study are consistent with a community-based cross-sectional study which showed that the prevalence of acute RTI was about $22-27 \%$ among children below five years of age in Eastern and Southern parts of India [15, 16]. Pneumonia and diarrhoea were the two causes accounting for $50 \%$ of infant deaths in India. Among these, pneumonia caused five-times higher mortality rates in girls in central India than boys, while diarrhoea in South Indian boys had a four-times higher mortality rate than girls in West India [17]. But a recent study conducted in Ujjain, India demonstrated that UTIs were the most common bacterial infection in infants with equal distribution of sex [7]. This concluded the geographic variation of the type of bacterial infection among infants. The bacterial infection in the respiratory tract may be probably associated with viral infections of the lower respiratory tract [18]. 


\begin{tabular}{|c|c|c|c|c|c|c|}
\hline $\begin{array}{l}\text { Type of } \\
\text { sample }\end{array}$ & $\begin{array}{l}\text { Type of } \\
\text { bacterial } \\
\text { infection }\end{array}$ & Gender & $\begin{array}{l}\text { Bacterial } \\
\text { isolate } \\
\text { identified }\end{array}$ & Sensitive antibiotics & Resistant antibiotics & $\begin{array}{r}\text { Bacteriological } \\
\text { and antibiotic } \\
\text { profile }\end{array}$ \\
\hline \multirow[t]{5}{*}{ Stool } & \multirow[t]{5}{*}{$\begin{array}{l}\text { Diarrhoea } \\
n=22 / 218 \\
(10.0 \%)\end{array}$} & \multirow[t]{5}{*}{$\begin{array}{l}\mathrm{M}=10 / \\
22 \\
(45.4 \%) \\
\mathrm{F}=12 / \\
22 \\
(54.5 \%)\end{array}$} & \multirow[t]{2}{*}{$\begin{array}{l}\text { P. aeruginosa } \\
(2 / 22,9.0 \%)\end{array}$} & \multirow[t]{2}{*}{$\begin{array}{l}\text { Imipenem, } \\
\text { Piperacilin }+ \text { tazobactem }\end{array}$} & \multirow{4}{*}{$\begin{array}{l}\text { Ciprofloxacin, } \\
\text { Amoxicillin } \\
\text { Netilmicin, } \\
\text { Gentamicin, } \\
\text { Amikacin, } \\
\text { Ceftazidine, } \\
\text { Cephalexin, } \\
\text { Cefuroxime, } \\
\text { Co-trimaxazole, } \\
\text { Tigecycline } \\
\text { Gentamicin, } \\
\text { Amoxicillin, } \\
\text { Ciprofloxacin, } \\
\text { Cephalexin, } \\
\text { Cefotaxim, } \\
\text { Co-trimaxazole } \\
\text { Ciprofloxacin, } \\
\text { Amoxicillin } \\
\text { Azithromycin }\end{array}$} & 237 \\
\hline & & & & & & \\
\hline & & & $\begin{array}{l}\text { E. } \operatorname{coli}(19 / 22, \\
86.3 \%)\end{array}$ & $\begin{array}{l}\text { Chloramphenicol, } \\
\text { Amikacin, } \\
\text { piperacilin + tazobactem } \\
\text { Netilmicin, Tigecycline, } \\
\text { Imipenem }\end{array}$ & & \\
\hline & & & \multirow[t]{2}{*}{$\begin{array}{l}\text { S. aureus }(1 / 22 \text {, } \\
4.5 \% \text { ) (MRSA) }\end{array}$} & \multirow[t]{2}{*}{$\begin{array}{l}\text { Netilmicin, Vancomycin, } \\
\text { Linezolid }\end{array}$} & & \\
\hline & & & & & $\begin{array}{l}\text { Penicillin, Cloxacillin, } \\
\text { Gentamicin, } \\
\text { Cephalexin, } \\
\text { Erythromycin, } \\
\text { Amikacin }\end{array}$ & $\begin{array}{r}\text { Table 4. } \\
\text { Distribution of } \\
\text { bacterial infection } \\
\text { among infants } \\
\text { presented with } \\
\text { diarrhoea }\end{array}$ \\
\hline
\end{tabular}

This study revealed that infections in male infants were more prevalent than amongst females. The exact reason for this remains elusive. This finding is also similar to studies conducted at Ahmedabad district in Gujarat, India, and Kancheepuram district in South India $[16,19]$. Among the total cases analysed during the study period, more than $90 \%$ of cases were with the acute febrile syndrome. Mendez Espinola and Herrera Labarca reported that children less than 3 months were hospitalized due to acute febrile syndrome [20]. Fever was the most frequently reported sign among neonates in India [21]. For the empiric treatment of infants below 60 days of age, presented with a suspected invasive bacterial infection, the narrowest spectrum antimicrobial therapy was recommended. Furthermore, there should be a more tolerable side effect profile. Results of the recent study demonstrated that cotrimoxazole and amoxicillin were the two antibiotics that were commonly recommended against Acinetobacter [22]. According to a recent study, the combination of ampicillin plus either gentamicin or a third-generation cephalosporin was an appropriate empiric antimicrobial treatment regimen [11]. However, de Man et al. reported that the use of thirdgeneration cephalosporin caused the development of resistant bacteria [23]. Greenhow and Cantey also concluded that for empiric use in most infants with suspected bacteremia, ampicillin plus gentamicin was an effective combination while awaiting results of bacterial culture. This combination has a lower risk of toxicity with once-daily dosing [24]. Pokhrel et al. recommend a combination of piperacillin-tazobactam and ofloxacin as the first-line therapy and a combination of vancomycin and meropenem as the second-line empirical therapy in infants admitted with sepsis in a neonatal intensive care unit [25]. The most 
JHR

238

Table 5.

Distribution of bacterial infection among infants presented with meningitis, bacteremia and otitis media

Figure 1.

Distribution of bacteria among infants presented with infection. CoNS: Coagulase-negative staphylococci, MRSA: Methicillin resistant $S$. aureus.

\begin{tabular}{|c|c|c|c|c|c|}
\hline $\begin{array}{l}\text { Type } \\
\text { of } \\
\text { sample }\end{array}$ & $\begin{array}{l}\text { Type of } \\
\text { bacterial } \\
\text { infection }\end{array}$ & Gender & $\begin{array}{l}\text { Bacterial isolate } \\
\text { identified }\end{array}$ & Sensitive antibiotics & $\begin{array}{l}\text { Resistant } \\
\text { antibiotics }\end{array}$ \\
\hline $\mathrm{CSF}$ & $\begin{array}{l}\text { Meningitis } \\
n=1 / 218 \\
(0.4 \%)\end{array}$ & $\begin{array}{l}M=0 \\
F=1 / 1 \\
(100 \%)\end{array}$ & $\begin{array}{l}\text { S. aureus }(1 / 1,100 \%) \\
\text { (MSSA) }\end{array}$ & $\begin{array}{l}\text { Gentamicin, Cloxacillin, } \\
\text { Azithromycin, Cefuroxime, } \\
\text { Cephalexin, Cefotaxime, } \\
\text { Vancomycin, Linezolid, } \\
\text { Netilmycin } \\
\text { Amoxicillin }\end{array}$ & $\begin{array}{l}\text { Penicillin, } \\
\text { Erythromycin }\end{array}$ \\
\hline Blood & $\begin{array}{l}\text { Bacteremia } \\
n=1 / 218 \\
(0.4 \%)\end{array}$ & $\begin{array}{l}\mathrm{M}=1 / \\
1 \\
(100 \%) \\
\mathrm{F}=0\end{array}$ & $\begin{array}{l}\text { Coagulase- } \\
\text { negative staphylococci } \\
(1 / 1,100 \%) \\
\text { (Methicillin resistant) }\end{array}$ & $\begin{array}{l}\text { Netilmicin, Vancomycin } \\
\text { Linezolid }\end{array}$ & $\begin{array}{l}\text { Amoxicillin, } \\
\text { Erythromycin, } \\
\text { Gentamicin, } \\
\text { Cloxacillin, } \\
\text { Penicillin, } \\
\text { Cephalexin, } \\
\text { Cefuroxime, } \\
\text { Cefotaxime, } \\
\text { Azithromycin }\end{array}$ \\
\hline Ear & $\begin{array}{l}\text { Otitis media } \\
n=4 / 218 \\
(1.8 \%)\end{array}$ & $\begin{array}{l}\mathrm{M}=2 \\
14 \\
(50 \%) \\
\mathrm{F}=2 / 4 \\
(50 \%)\end{array}$ & $\begin{array}{l}\text { P. aeruginosa }(4 / 4, \\
100 \%)\end{array}$ & $\begin{array}{l}\text { Imipenem, } \\
\text { piperacillin + Tazobactem, } \\
\text { Polymixin B }\end{array}$ & $\begin{array}{l}\text { Ciprofloxacin, } \\
\text { Amoxicillin } \\
\text { Netilmicin, } \\
\text { Gentamicin, } \\
\text { Amikacin, } \\
\text { Ceftazidine, } \\
\text { Cephalexin, } \\
\text { Cefuroxime, } \\
\text { Co-trimaxazole }\end{array}$ \\
\hline
\end{tabular}

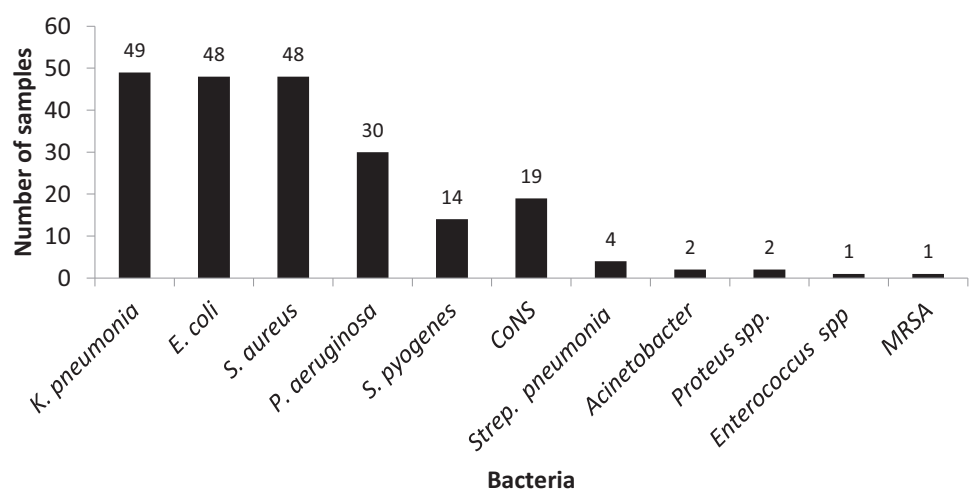

sensitive antibiotic against bacteria isolated from a throat swab and CSF samples was gentamicin and cloxacillin. Netilmicin and piperacillin plus tazobactam were the sensitive antibiotics against bacteria isolated from urine, stool, and ear secretion samples. Empirical therapy using piperacillin + tazobactam and netilmicin was found to be effective with good tolerance in infants and even in neutropenic children with fever [26, 27]. However, in vitro susceptibilities do not necessarily correlate with in vivo effectiveness [2]. Hence, an empirical antibiotic regimen as per the updated antibiotic policy should be developed based on an 
individualized community established antimicrobial sensitivity pattern of microorganisms to prevent morbidity and mortality in infants $[3,28]$. Short duration and small sample size representing the population were the major limitations of this study. Further, a multicentre population-based study is warranted to develop a protocol/policy/rational use of antibiotics in the clinical setting for empiric therapy.

Despite the empirical antibiotic treatment in subjects presented with infection in the post -neonatal period, awareness about exclusive breastfeeding, maternal and neonatal immunizations, and antibiotic prophylaxis in case of suspected infection are warranted to reduce the incidence of infection. Furthermore, keeping the baby's environment clean, keeping a safe distance from people who are unwell, or avoiding contact with infected people are major home-based activities to protect infants from common infectious diseases. Changing diapers at frequent intervals can reduce occurrence of a UTI and washing the child's and caregiver's hands frequently can prevent food and respiratory infections. Therefore, practicing good hygiene in child care is the best way to prevent infection. Community-based awareness and education should be given to parents in order to follow regular good hygiene in childcare. Furthermore, avoiding delay in seeking treatment and providing the medicine prescribed at the right time and in the right dose limits morbidity and bacterial resistance.

\section{Conclusion}

Upper RTI is the major bacterial infection and Klebsiella is the major organism causing infection in infants in their post-neonatal period. The common antibiotic found sensitive against bacteria isolated from throat swab was gentamicin and cloxacillin. Netilmicin and piperacillin plus tazobactam were the sensitive antibiotics against bacteria isolated from other sources. Community-based awareness should be provided to follow good hygiene in child care.

\section{Conflict of Interest: None}

\section{References}

1. Poletto E, Zanetto L, Velasco R, Da Dalt L, Bressan S. Bacterial meningitis in febrile young infants acutely assessed for presumed urinary tract infection: a systematic review. Eur J Pediatr. 2019; 178(10): 1577-87. doi: 10.1007/s00431-019-03442-4.

2. Byington CL, Rittichier KK, Bassett KE, Castillo H, Glasgow TS, Daly J, et al. Serious bacterial infections in febrile infants younger than 90 days of age: the importance of ampicillin-resistant pathogens. Pediatrics. 2003; 111(5 Pt 1): 964-8. doi: 10.1542/peds.111.5.964.

3. Wang ME, Patel AB, Hansen NI, Arlington L, Prakash A, Hibberd PL. Risk factors for possible serious bacterial infection in a rural cohort of young infants in central India. BMC Publ. Health. 2016; 16(1): 1097. doi: 10.1186/s12889-016-3688-3.

4. Dharmapalan D, Shet A, Yewale V, Sharland M. High reported rates of antimicrobial resistance in indian neonatal and pediatric blood stream infections. J Pediatric Infect Dis Soc. 2017; 6(3): e62-e8. doi: 10.1093/jpids/piw092.

5. Batra P, Gupta S, Gomber S, Saha A. Predictors of meningitis in children presenting with first febrile seizures. Pediatr Neurol. 2011; 44(1): 35-9. doi: 10.1016/j.pediatrneurol.2010.07.005.

6. Goel S, Mukherjee SB. Urinary tract infection, a tale of 50 years. Indian Pediatr. 2016; 53(1): 57-8. doi: 10.1007/s13312-016-0792-5.

7. Pathak A, Upadhayay R, Mathur A, Rathi S, Lundborg CS. Incidence, clinical profile, and risk factors for serious bacterial infections in children hospitalized with fever in Ujjain, India. BMC Infect Dis. 2020; 20(1): 162. doi: 10.1186/s12879-020-4890-6.
Bacteriological and antibiotic profile

239 
JHR

36,2

8. Yadav NS, Sharma S, Chaudhary DK, Panthi P, Pokhrel P, Shrestha A, et al. Bacteriological profile of neonatal sepsis and antibiotic susceptibility pattern of isolates admitted at Kanti Children's Hospital, Kathmandu, Nepal. BMC Res Notes. 2018; 11(1): 301. doi: 10.1186/s13104-0183394-6.

9. Coles CL, Rahmathullah L, Kanungo R, Thulasiraj RD, Katz J, Santosham M, et al. Nasopharyngeal carriage of resistant pneumococci in young South Indian infants. Epidemiol Infect. 2002; 129(3): 491-7. doi: 10.1017/s0950268802007586.

10. Million Death Study Collaborators. Changes in cause-specific neonatal and 1-59-month child mortality in India from 2000 to 2015: a nationally representative survey. Lancet. 2017; 390(10106): 1972-80. doi: 10.1016/S0140-6736(17)32162-1.

11. Woll C, Neuman MI, Pruitt CM, Wang ME, Shapiro ED, Shah SS, et al. Epidemiology and etiology of invasive bacterial infection in infants $\leq 60$ days old treated in emergency departments. J Pediatr. 2018; 200: 210-7. doi: 10.1016/j.jpeds.2018.04.033.

12. Forbes BA, Sahm DF, Weissfeld AS. Bailey and Scott's diagnostic microbiology. Part III: Bacteriology. 12th ed. St. Louis: Mosby Elsevier; 2007: 216-533.

13. Bauer AW, Kirby WM, Sherris JC, Turck M. Antibiotic susceptibility testing by a standardized single disk method. Am J Clin Pathol. 1966; 45(4): 493-6.

14. Clinical and Laboratory Standards Institute [CLSI]. Performance standards for antimicrobial susceptibility testing. CLSI supplement M100. 29th ed. Wayne, Pennsylvaniya, PA: CLSI; 2019.

15. Islam F, Sarma R, Debroy A, Kar S, Pal R. Profiling acute respiratory tract infections in children from Assam, India. J Glob Infect Dis. 2013; 5(1): 8-14. doi: 10.4103/0974-777X.107167.

16. Prajapati B, Talsania NJ, Lala MK, Sonalia KN. Epidemiological profile of acute respiratory infections (ARI) in under five age group of children in urban and rural communities of Ahmedabad district, Gujarat. Int J Med Sci Public Health. 2012; 1(2): 52-8. doi: 10.5455/ijmsph. 2012.1.52-58.

17. Million Death Study Collaborators, Bassani DG, Kumar R, Awasthi S, Morris SK, Paul VK, et al. Causes of neonatal and child mortality in India: a nationally representative mortality survey. Lancet. 2010; 376(9755): 1853-60. doi: 10.1016/S0140-6736(10)61461-4.

18. Hall CB, Powell KR, Schnabel KC, Gala CL, Pincus PH. Risk of secondary bacterial infection in infants hospitalized with respiratory syncytial viral infection. J Pediatr. 1988; 113(2): 266-71.

19. Sharma D, Kuppusamy K, Bhoorasamy A. Prevalence of acute respiratory infections (ARI) and their determinants in under five children in urban and rural areas of Kancheepuram district, South India. Ann Trop Med Public Health. 2013; 6(5): 513-8. doi: 10.4103/1755-6783.133700.

20. Mendez Espinola BM, Herrera Labarca P. Children less than 3 months hospitalised due to acute febrile syndrome: 5 years clinical experience. Rev Chil Pediatr. 2015; 86(4): 270-8. doi: 10.1016/j. rchipe.2015.02.001.

21. Panigrahi P, Chandel DS, Hansen NI, Sharma N, Kandefer S, Parida S, et al. Neonatal sepsis in rural India: timing, microbiology and antibiotic resistance in a population-based prospective study in the community setting. J Perinatol. 2017; 37(8): 911-21. doi: 10.1038/jp.2017.67.

22. Biondi EA, Mischler M, Jerardi KE, Statile AM, French J, Evans R, et al. Blood culture time to positivity in febrile infants with bacteremia. JAMA Pediatr. 2014; 168(9): 844-9. doi: 10.1001/ jamapediatrics.2014.895.

23. de Man P, Verhoeven BA, Verbrugh HA, Vos MC, van den Anker JN. An antibiotic policy to prevent emergence of resistant bacilli. Lancet. 2000; 355(9208): 973-8. doi: 10.1016/s0140-6736(00) 90015-1.

24. Greenhow TL, Cantey JB. The disputed champion: ampicillin and gentamicin for febrile young infants. Hosp Pediatr. 2017; 7(8): 499-501. doi: 10.1542/hpeds.2017-0101.

25. Pokhrel B, Koirala T, Shah G, Joshi S, Baral P. Bacteriological profile and antibiotic susceptibility of neonatal sepsis in neonatal intensive care unit of a tertiary hospital in Nepal. BMC Pediatr. 2018; 18(1): 208. doi: 10.1186/s12887-018-1176-x. 
26. Salerno S, Hornik CP, Cohen-Wolkowiez M, Smith PB, Ku LC, Kelly MS, et al. Use of population pharmacokinetics and electronic health records to assess piperacillin-tazobactam safety in infants. Pediatr Infect Dis J. 2017; 36(9): 855-9. doi: 10.1097/inf.0000000000001610.

27. Le Guyader N, Auvrignon A, Vu-Thien H, Portier E, Tabone MD, Leverger G. Piperacillintazobactam and netilmicin as a safe and efficacious empirical treatment of febrile neutropenic children. Support Care Cancer. 2004; 12(10): 720-4. doi: 10.1007/s00520-004-0641-2.

28. Seliem WA, Sultan AM. Etiology of early onset neonatal sepsis in neonatal intensive care unit Mansoura, Egypt. J Neonatal Perinatal Med. 2018; 11(3): 323-30. doi: 10.3233/NPM-17128.

Bacteriological and antibiotic profile

\section{Corresponding author}

Santhosh J. Thattil can be contacted at: drsanthoshjohnthattil@gmail.com

For instructions on how to order reprints of this article, please visit our website: 